\title{
A High-Throughput Microenvironment for Single-Cell Operations
}

A. Christian, P. Buckley, R.R. Miles

January 7, 2003

U.S. Department of Energy

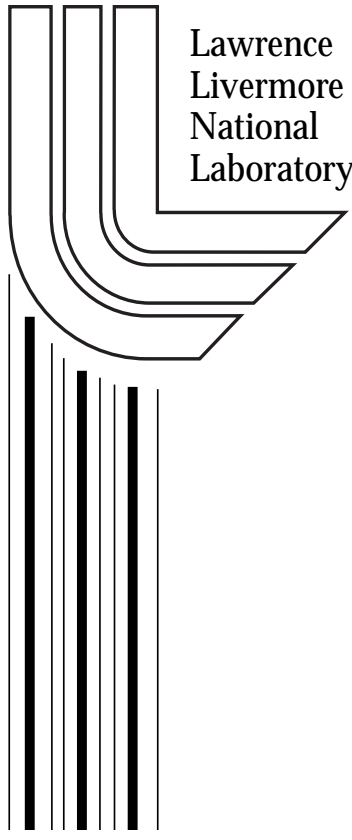




\section{DISCLAIMER}

This document was prepared as an account of work sponsored by an agency of the United States Government. Neither the United States Government nor the University of California nor any of their employees, makes any warranty, express or implied, or assumes any legal liability or responsibility for the accuracy, completeness, or usefulness of any information, apparatus, product, or process disclosed, or represents that its use would not infringe privately owned rights. Reference herein to any specific commercial product, process, or service by trade name, trademark, manufacturer, or otherwise, does not necessarily constitute or imply its endorsement, recommendation, or favoring by the United States Government or the University of California. The views and opinions of authors expressed herein do not necessarily state or reflect those of the United States Government or the University of California, and shall not be used for advertising or product endorsement purposes.

This work was performed under the auspices of the U. S. Department of Energy by the University of California, Lawrence Livermore National Laboratory under Contract No. W-7405-Eng-48.

This report has been reproduced directly from the best available copy.

Available electronically at http://www.doc.gov/bridge

Available for a processing fee to U.S. Department of Energy

And its contractors in paper from

U.S. Department of Energy

Office of Scientific and Technical Information

P.O. Box 62

Oak Ridge, TN 37831-0062

Telephone: (865) 576-8401

Facsimile: (865) 576-5728

E-mail: reports@adonis.osti.gov

Available for the sale to the public from

U.S. Department of Commerce

National Technical Information Service

5285 Port Royal Road

Springfield, VA 22161

Telephone: (800) 553-6847

Facsimile: (703) 605-6900

E-mail: orders@ntis.fedworld.gov

Online ordering: http://www.ntis.gov/ordering.htm

OR

Lawrence Livermore National Laboratory

Technical Information Department's Digital Library

http://www.llnl.gov/tid/Library.html 


\section{PURPOSE}

This project was conducted as a feasibility study, in preparation for including this work in the forthcoming 'Instrumented Cell' (IC) Strategic Initiative. The goal of the IC is to study individual cells; the goal of this feasibility study was to determine the best method for isolating large numbers of individual cells in a way that facilitates various types of environmental changes and intracellular measurements. We have the capability to do this with one cell, and sought to expand the number of cells that we could study simultaneously. Our specific goal for this feasibility study was to discover a way to isolate individual cells, and impale them on a nanopipette. This would enable samples to be introduced into and removed from a cell.

\section{TECHNICAL APPROACH}

Dielectrophoresis: A fixture was made to hold a gold metalized pipette perpendicular to a gold metalized cover slip. This fixture was a slotted piece of Delran. The slot was the width of a cover slip and had a screw mount for the securment of the pipette. The metalized pipette and cover slip had leads soldered onto them and these were connected to the amplifier and signal generator. The end of the pipette was placed approximately 80-100 microns away from the cover slip. This distance was difficult to determine. The slot was then filled with a solution of HMO cells suspended in a sugar solution consisting of distilled water, $8.5 \%$ sucrose, and $0.3 \%$ dextrose. The conductivity of this solution was measured at $7 \mathrm{~S} / \mathrm{cm}$. An AC current was then applied between the pipette and the cover slip. A large range of frequencies and voltages were tried; the frequency would be adjusted to $15 \mathrm{MHz}$ and a voltage set. The frequency was then lowered slowly while maintaining the same voltage. As the frequency was dropped, the pipette tip was watched for any cell accumulation. This procedure was repeated using different voltages. Below $50 \mathrm{~V}$ there was no observable motion of cells. Above 50 $\mathrm{V}$ and in the range of frequencies $2 \mathrm{MHz}-800 \mathrm{KHz}$ there was a striking buildup of cells on the end of the pipette. Figures 1, 2 and 3 show the progression of cell buildup on the end of the pipette (taken at 10x magnification). The fuzzy haze around the pipette tip in figures 2 and 3 are cells. This buildup happened in about 4-5 minutes.

Fig. 1

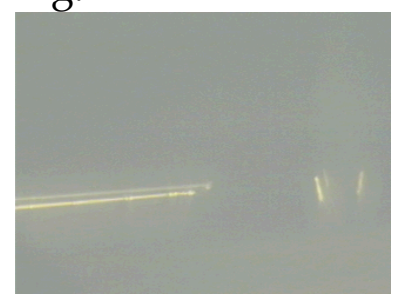

Before Voltage applied
Fig. 2

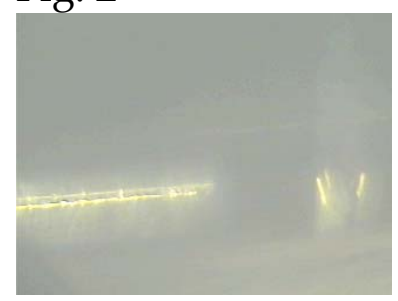

80 Volts $2 \mathrm{MHz}$
Fig. 3

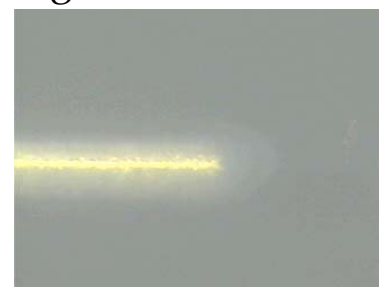

80 Volts $2 \mathrm{MHz}$ 
However, it was impossible to determine if a cell was impaled on the end of the pipette, the buildup of cells made it impossible to make out the tip. It was conclusive that there was a strong draw of cells towards the pipette. Whether this dielectrophoretic force can generate enough directed force to impale a cell onto a pipette tip would require further investigation.

Fluid flow/entrapment: Since the technique of simultaneous entrapment and impalement seemed impractical based on experimentation, the method upon which we settled was a two-part process; first the cells are trapped in a flowthrough box, and then they are impaled. An array of flow-capture boxes was designed as shown in Figure 4. The intent was for the cell to flow into the box. The glass membrane could be deflected such that the cell could be impaled on the micro-fabricated silicon needle as shown in Figure 5.

The boxes were constructed using SU-8, a photopatternable epoxy spun on a flexible glass wafer. A reverse pattern was made by using the SU-8 as a mold for a silicone version of the holes. This in effect, created raised 'boxes' instead of holes. The results showed that depression were effective, as seen in Figure 6. Further work could certainly be done to optimize the capture box design. For example, scalloping of the edges could be added to retain the cells better. The silicon microneedle work, necessary to impale and sample the cells, is feasible with this approach but could not be completed within the duration of this project.

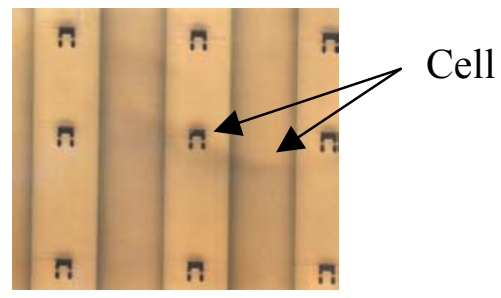

Figure 4. Top View of Cell Holders

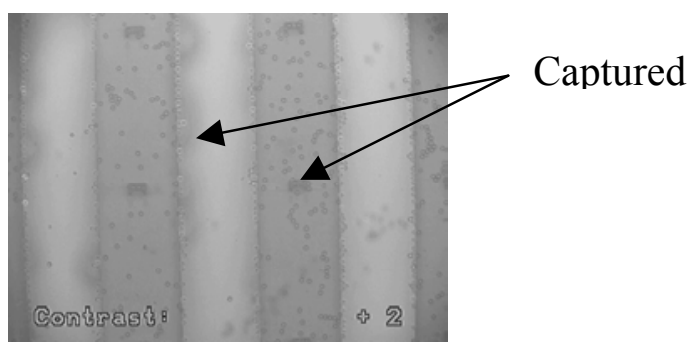

Figure 6. Captured Beads

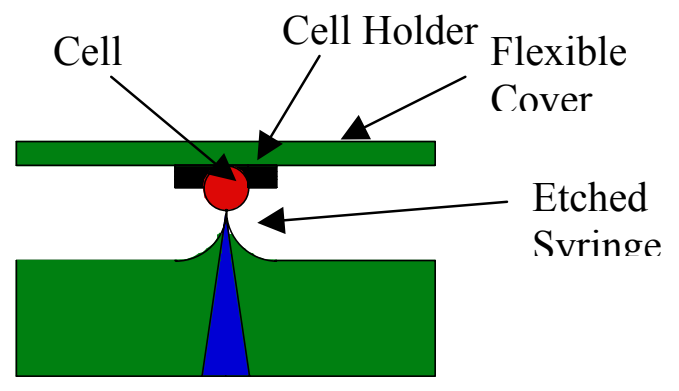

Figure 5. Silicon Micro-needle 


\section{CONCLUSIONS}

The results showed that depressions were effective in capturing cells; further work needs to be done to optimize the capture box design. This design appears to be viable, and has the advantage over needles of allowing both freefloating and medium-attached cells to be examined. The size of the capture wells can be varied, depending on the size of the cells to be studied. We feel that this prototype can be developed to serve as a platform for the single-cell analyses upon which the Instrumented Cell initiative is predicated. 